\title{
How Interlanguage Process of Students L2 During the Pandemic Era?
}

\author{
Nurul Mahfuza \\ Universitas Negeri Padang \\ email: nurulmahfuza4@gmail.com
}

\begin{abstract}
During the COVID-19 pandemic, all activities are carried out virtually and the learning process is included in the effort to learn the target language (IL) in the Interlanguge process. The purpose of this article is to identify what applications students use in their respective L2 processes in the interlanguage process. To collect data in this study, researchers used interviews. Data collection was carried out by interviewing with the help of an interview guide conducted with 6 students of SMK Amal Ikhlas Kampar. The results of this study indicate that students use the Youtube application to achieve the target language mastery level in the inter-language process.
\end{abstract}

Keywords: Target Language (L2), Interlanguage, COVID-19 Pandemic, Youtube

\section{Introduction}

Teaching and learning practices in general and L2 educational activities in particular are constantly changing due to technological advances (Kerawalla, Luckin, Seljeflot, \& Woolard, 2006). The present youthful age can really be considered as advanced locals; thus, the utilization of innovation in training becomes more straightforward and learning turns out to be seriously inspiring, significant, and phenomenal (Singhal, Bagga, Goyal, and Saxena, 2012). This review means to perceive how the most common way of obtaining and learning a second language during the Coronavirus Ig scourge is utilizing advanced complexity through accessible applications.

Given the significance of commonsense information in second language advancement, the utilization of viable approaches and procedures to work on the even minded skill of second language students in the objective language has become vital, particularly in unknown dialect settings (Bardovi- Harling, 1999; Jianda, 2010; Tajeddin, Alemi, and Pashmforoosh, 2018; Xu, Case, and Williams, 2017). However, right now we are confronted with a Coronavirus pandemic circumstance where movements of every kind are done from home. This approach affects the act of learning a subsequent language. Indeed, the most common way of learning a subsequent language can normally be acquired through friendly exercises by seeing and taking in a second language from the general climate.

Since the first interlanguage conception by Selinker in 1972, the methods of interlanguage study have encountered an arrangement of reformulations to elude the ,comparative fallacy"e of target language comparisons. This move has provoked the elective term, 'student language', the oral and composed language by second language students'. Due to the covid - 19 pandemic era, this present research will analyze how interlanguage process of students in achieving their 12 during the pandemic covid-19 era. Furthermore, there are still very few numbers of studies on Indonesian learners' of English has been done, later, the present study will be central to conduct research in this area.

\section{Defining Interlanguage (IL)}


Language is what the society speak. It means that As social beings, people have to communicate with each other and in communicating, everyone is different. They communicate in various language dependent on the circumstance. for non-native speakers, language learning is carried out with or without guidance, and the process of mastering a second language is referred to as interlanguage. After finishing mastering the first language, namely the mother tongue, students will get familiar with another dialect (second, third, unfamiliar), it was called SLA. Be that as it may, unknown dialect taking in normally not quite the same as Second Language Obtaining which the previous arrangements to the learning of a nonnative language in the natural surroundings of onees local language.

Learning a Second language was not much explored until the mid-twentieth century. This is beginning to be observed as well as learning the first language that was learned in the late 1960s. This era began with Fries (1945) with "Contrastive Analysis/CA" and Lado (1957), who insisted on the need to compare native language learners (NL) with their target language (Target Language/TL). to find out the most appropriate teaching materials. Dissatisfied with this insight, there is another theory, the theory which has come to be known as "Error Analysis" (EA). This theory stems from the opinion that learning is basically a process that involves making mistakes (Brown, 1987). Eventually these two theories later developed into the theory of "interlanguage" (Interlanguage/IL), which was consolidated by Selinker in 1997 Review of Related Theories

Among the intellectual systems noted by Chamot (1987) are reiteration, note-taking, and elaboration. Intellectual systems, for example, these give off an impression of being straightforwardly identified with the execution of specific learning undertakings. Second, the metacognitive procedure uses information about intellectual cycles and is an endeavor to control language learning through arranging, observing, and assessment. These are determinant capacities.

Guided focus toward focusing on specific parts of language info, and self-administration, presents conditions that help learning and empower attempting. Third, social/emotional procedures, focus on the manners in which understudies decide to collaborate with different understudies and local speakers. Instances of this classification are "participation", working with different partners to get criticism, gathering data, or displaying semantic exercises, and "inquiries for explanation", asking an educator or other local speaker for redundancy, rework clarification, or models.

\section{Processes Involved in Interlanguage}

Interlanguage, which evolved from the theories of Contrastive Analysis and Error Analysis, is compatible with second language acquisition. It is about understanding the type of student's internal language production. Students who are not makers of the objective language are defective, loaded with botches. In any case, as astute and inventive creatures, they continue through phases of coherent, deliberate, and imaginative obtaining of adjusting to their phonetic climate as they experience their structure and capacity in a significant setting (Brown, 2000). It seems that this intermediate language theory is more acceptable because it focuses on the cognitive and social processes of learners.

Selinker cegories five significant cycles that influencing IL conduct. He distinguishes these as: language move, systems of second language correspondence, move of preparing, procedures of second language learning, and over-speculation of the TL semantic material (Selinker, 1997).

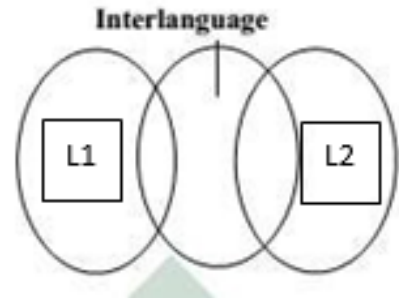

Figure 1. The Notion of the IL 
As indicated by Selinker (1997), in IL incorporate a few examples, for example: Acquiring patters from his/her native (language move), Expanding designs from the TL (overgeneralization), Communicating importance utilizing the words and punctuation which are now known by the student (correspondence technique), Applying what they have gained from their educators or course books (move of preparing), and A cognizant endeavor by the language students to dominate the TL (systems of learning).

Notwithstanding, he additionally brought up that past the five focal cycles, there exist numerous different cycles which record somewhat for the surface type of IL expressions. Selinker (1997) present the term interlanguasge (IL) to the halfway states (or break syntaxes) of a students' language as it push toward the objective L2. There are two idea of interlanguage. In the first place, interlanguage alludes to the organized framework which the student builds at some random stage in his turn of events (for example an interlanguage). Second, the term alludes to the series of interlocking frameworks which structure what Corder (1967) called the student's 'implicit schedule's (for example the interlanguage continuum).

The term interlanguage alludes to the precise pocess of get-together the second language by the distinct individuals. While impact from L1 and L2 language frameworks' in a students IL is obviously perceived, accentuation is on the actual IL as a third language situation by its own doing which varies from both L1 and L2 throughout its turn of events.

\section{The Process and Characteristics of Interlanguage}

There are five chief cycles worked in interlanguage. For example: Language transfren L1 to L2, Overgeberalization move of Target language rules, Move of preparing, Systems of L2 learning, techniques of L2 correspondence. An interlanguage has the accompanying attributes, for example: (1) Orderly. Regardless of interlanguage certain individuals are orchestrate by the inward language when they talk, which the individual can create and decipher accurately just as mistakes that are made. (Dynamic). The arrangement of rules which students have to them changes much of the time, or is in a condition of transition, bringing about a progression of interval language structures. (3)Permeable. The L2 student's interlanguage framework is penetrable, as in decides that comprise the student's information at any one phase are not fixed, however are available to revision.

\section{Methods}

This research is a descriptive research and to achieve the objectives of this research. This research is a survey research that uses interviews to collect data. To analyze the data, the researcher used a descriptive approach to write the results of this study. This research was conducted at the Ikhlas Amal Vocational School in Tapung, Kampar Province. In this school, students use English as a means of communication in their daily life. The research was carried out in September-November 2021. The resource persons for this research data were 6 students of SMKS Amal Ihlkas to be studied. Researchers will ask several questions related to their process in the 12th learning in the pandemic era. The author also conducted a literature study and took online sources such as journals and related online sites that support and provide information.

Some of the questions asked in the interview included: (1) How do students learn English during a pandemic? (2) Where do students usually get their second language learning from? (3) What applications do students often use in second language learning in the era before the pandemic? (4) What applications do students often use in learning a second language during the pandemic? (5) How often do students open application options in second language learning? (6) Which is more effective in learning a second language using electronic social media or direct learning by observing the surrounding environment?

Students are asked to answer the questions that have been asked to gain their understanding in learning their L2 languages at the interlingual stage during the current pandemic. Then after the data was collected, the researcher concluded the results with a descriptive approach. The dominant answer 
becomes the research reference in drawing conclusions. In this study, it is stated that what application is dominantly used by students in gaining understanding in studying their L2 at the interlanguage stage during the current pandemic.

\section{Result and Discussion}

The results of the interview show that almost all students learn the target language by looking around and trying to remember sentences in English that they often hear. However, during the current epidemic, it requires students to study at home and makes them rarely interact with social directly. Therefore they say that in the interlangue process, the brand learns English by using applications available on the internet. All students are important in choosing the YouTube application to improve their understanding in learning the target language. According to them, the use of this YouTube application is very useful in the interlanguge process where they can learn English correctly and pronunciation and they can repeat the learning videos and do their own practice in their respective homes.

In accordance with the discoveries of the main examination question, there are a few analysts who propose that virtual learning is useful for ESL/EFL students during the time spent second language advancement. for instance, expresses that in virtual jargon learning, understudies' consideration is on the substance of the message conveyed rather than on remembering jargon things. Moreover, he expressed that uncommon jargon learning can happen when the quantity of obscure jargon is low.

One more review is Robinson (2005, refered to in Takimoto, 2013) who studied the viability of learning the virtual normal language of Samoan as an unknown dialect. The members are Japanese college understudies. Then again, there are different examinations that advocate genuine homeroom guidance and the learning of second language jargon, syntax, and surprisingly a realistic part. Schmidt (1993, cited in Suvanto, 2013, p. 24) contends that "virtual learning is conceivable and happens at a specific level, guiding understudies' focus toward applicable highlights in the info is useful in gaining practical skill". Suvanto (2013, p. 25) contends "for mindfulness bringing procedures up in showing logical skill" accentuating that "it is profoundly improbable that students will unintentionally and verifiably become familiar with an objective language highlight" (see likewise Tajeddin and Hosseinpour, 2014 for some proposed strategies) .

Schmidt (2010) clarifies that learning in virtual and genuine classes can build understudies' verbal mindfulness. Hulstijin's examination (2011) shows that study hall instructing as a conscious endeavor to retain new words or articulations works with the procurement of words or articulations without the expectation of fusing the components into memory. Hypothetically, Ellis (2008) contends that up close and personal homeroom learning includes a purposeful work to realize, which might include mindfulness while virtual learning is bound to be deliberate realizing, which might include impromptu regard for some different highlights. from L2 like a decent order of articulations, shoptalk, and language.

There is a significant assortment of ongoing exploration, however, affirming that genuine study hall communications and learning of some objective language ideas, like pragmatics and social issues of the objective language, are more fruitful than their virtual learning. Gironzetti and Koike (2016) analyzed two kinds of guidance, virtual and genuine, in advancing educational methods pointed toward overcoming any issues in Spanish informative pragmatics and observed that genuine study hall guidance was more effective.

\section{Conclusion}

Based on the information above, the online learning have to be more familiar for student. It can be concluded that learning English using youtube media is very exciting because there are many facilities that we can find on youtube so that students can choose according to their own wishes. English teaching materials are also widely available and can be accessed easily and quickly. Thusly, techonology has turned into a basic and indistinguishable piece of their learning, while in the Iranian setting (basically in 
the pre-Coronavirus time, when the examination was led). The schooling framework actually has a more extended course to exploit innovation in standard educating/learning conditions and not simply use it for amusement or similarly as a fringe valuable asset.

The discoveries infer that understudies at the earnest foundation professional school proceed to extend and get familiar with their objective language in any event, during the pandemic. They utilize advanced means to get familiar with their objective language, to be specific English by utilizing the YouTube application. they keep on rehearsing in accomplishing tage language.

\section{Acknowledgments}

I would like to thank the participants of this study who have helped me to get the results, so that I can write them in this article as well as to help readers, especially teachers, to be conscious of the problem stated in this investigation.

\section{References}

Allwright, R. L. and Kathleen, M. B. (1999). Focus on the language classroom: an introduction to classroom research for language teachers. Cambridge: C.U.P.

Bardovi-Harling, K. (1999). Exploring the interlanguage of interlanguage pragmatics: A research agenda for acquisitional pragmatics. Language Learning, 49 (4), 677-13.

Brown, D. (1987). Principles of language learning and teaching, $2^{\text {nd }}$. Prentice Hall. Englewood Cliffs : New Jersey.

Brown, H. D. (2000). Principles of language learning and teaching $\left(4^{\text {nd }}\right)$. White Plains, New York: Longman.

Ellis, R. (2008). Study of second language acquisition. Oxford: Oxford University Press.

Fromkin, V., Rodman, R., Collins, P. \& Blair, D. (1999). An introduction to language (4 $\left.{ }^{\text {nd }}\right)$. Harcourt Brace: Sydney.

Gironzetti, E., \& Koike, D. (2016). Bridging the gap in Spanish instructional pragmatics: from theory to practice. Journal of Spanish Language Teaching, 3(2), 89-98.

Hulstijin, J. (2011). Incidental learning in second language acquisition. In C. Chapelle (Ed.), The encyclopedia of applied linguistics (pp. 1-5). Oxford: Wiley-Blackwell.

Jianda, L. (2010). Assessing EFL learners' inter-language pragmatic knowledge: Implications for testers and teachers. Reflections on English Language Teaching, 5(1), 1-22.

Kathleen Bardovi-Harlig. (2006). Interlanguage Development Main Routes and Individual Paths. AILA Review. John Benjamins Publishing Company.

Kerawalla, L., Luckin, R., Seljeflot, S., \& Woolard, A. (2006). "Making it real": exploring the potential of augmented reality for teaching primary school science. Virtual Reality, 10(3), 163- 174. 
Savignon, S. J. (1997). Communicative competence: Theory and classroom practice (2nd ed.). New York: McGraw-Hill.Schmidt, R. (2010). Attention, awareness, and individual differences in language learning. Proceedings of CLaSIC 2010. Centre for Language Studies, 721-737. Singapore, National University of Singapore.

Selinker, L. (1997). Rediscovering interlanguage. London: Longman.

Singhal, S., Bagga, S., Goyal, P., \& Saxena, V. (2012). Augmented chemistry: Interactive education system. International Journal of Computer Applications, 49(15), 1-5.

Suvanto, K. (2013). A too ambiguous concept to be taught?: English teachers' notions of pragmatic competence. (Unpublished master's thesis). University of Jyväskylä, Jyväskylän yliopisto, Finland. October 2013.

Tajeddin, Z., Alemi, M., \& Pashmforoosh, R. (2018). Idealized nativespeaker linguistic and pragmatic norms in English as an international language: Exploring the perceptions of nonnative English teachers. Language and Intercultural Communication, 18(3), 300-314.

Takimoto, M. (2013). Exploring the effects of intention-oriented inputbased instruction in second language pragmatics: A case of English request hedges. The Journal of Asia TEFL, 10(4), 41- 69.

Xu, W., Case, R. E. \& Williams, G. M. (2017). Longitudinal pragmatic and grammatical development in English among Chinese Students. TESOL International Journal, 12(2), 65-77. 